\title{
A Study on the Rights Practice of Childcare Teachers in Home Daycare Centers
}

\author{
Gihwa Kim, Sungeun Yang \\ Department of Child Studies, Inha University, Incheon, Korea \\ 가정어린이집 보육교사들의 권리실제에 관한 질적 연구 \\ 김기화, 양성은 \\ 인하대학교 아동심리학과
}

Objective: The present study examined how childcare teachers at home daycare centers perceive their rights as teachers and what kind of rights situations pertain to them at their respective daycare centers.

Methods: Adopting a qualitative research method approach, this study conducted focus group interviews to collect empirical data. The participants were childcare teachers and directors at home daycare centers, which were shown to have relatively poor work environments compared to other types of daycare centers

Results: The findings revealed that the participants at home daycare centers perceived their rights as childcare teachers to be extremely vulnerable. It was shown that their rights could not be protected in various frameworks involving mutual relations between teachers and directors, the Infant Care Act and childcare policy, and social perceptions that fail to recognize them as professionals.

Conclusion: The fingdings from the present study contribute to our understanding of the rights situation faced by childcare teachers at home daycare centers and to the social discourse on finding ways to realize the teachers' full rights as childcare professionals.

Keywords: rights practice, home daycare centers, childcare teachers, qualitative research

\begin{abstract}
서론
여성의 경제활동 증가, 자녀양육 기능의 사회화, 정부의 무 상보육 정책 등으로 영유아의 어린이집 이용이 보편화되고 있다. 영유아의 어린이집 이용은 2010 년도 $1,279,910$ 명에서 2015년도에는 1,452,813명으로 증가하였다(Korea Institution Child Care and Education [KICCE], 2016). 어린이집을 이용하 는 영유아가 증가하고 어린이집에서의 생활시간이 길어짐에 따라 보육서비스 제공자인 보육교사의 자질과 역량이 중요시

Corresponding Author: Sungeun Yang, Department of Child Studies, Inha University, 100 Inha-ro, Nam-gu, Incheon 22212, South Korea

E-mail: syang@inha.ac.kr
\end{abstract}

된다. 문제는 보육교사에 의한 아동학대 사례가 최근 지속적 으로 보고된다는 점이다. 교사의 권리와 의무는 교육에 대한 교사의 기본적인 권리뿐만 아니라 교직에 종사하는 교사들이 그들의 책임과 의무를 수행함에 있어 보장받는 제반조건을 포 함한다(B. Y. Kim, 2011). 이에 보육교사의 권리는 보육업무 수 행 시 책임과 의무를 다할 수 있도록 보장된 환경제반을 의미 한다. 보육교사의 권리는 의무와 상호 연관성이 있으며, 최근 부각이 되고 있는 아동학대와 관련한 보육교사의 윤리 문제와 도 관련이 있다. 어린이집에서 발생한 아동학대 사건이 사회

(C)The Korean Association of Child Studies

This is an Open Access article distributed under the terms of the Creative Commons Attribution Non-Commercial License (http:// creativecommons.org/licenses/by-nc/4.0) which permits unrestricted noncommercial use, distribution, and reproduction in any medium, provided the original work is properly cited. 
적 쟁점이 되면서 정부는 영유아보육법을 개정하여 영유아 권 리보장에 대처하고 있다. 어린이집 CCTV 설치 의무화, 아동 학대 행위자에 대한 어린이집 설치 - 운영 및 근무 제한 강화, 아동학대 어린이집 및 행위자에 대한 처벌 강화 등이 구체적 시행방안이다. 또한, 보육교사의 질을 담보하기 위해 자격관 리 체계도 강화하고 있다.

영유아는 스스로 자신의 권리를 주장할 수 없기 때문에 부 모, 교사, 지역사회, 국가 차원에서 권리보장이 이루어져야 한 다. 영유아의 권리에 대한 학문적 관심은 아동학, 영유아보육 및 교육학, 사회복지학 분야 등에서 이루어지고 있다. 반면, 보 육서비스 제공자인 보육교사의 권리에 대한 사회적 관심은 상 대적으로 낮은 편이다. 일련의 아동학대 사례로 인해 보육교 사를 영유아의 권리를 침해할 수 있는 잠재적 가해자로 간주 하는 왜곡된 시각이 있는 것도 현실이다. 중요한 것은 영유아 의 권리와 보육교사의 권리가 상호독립적인 것이 아니라는 것 이다. Seo (2010)는 아동권리존중 보육을 위해서는 교사의 권 리도 보장되어야하며, 전문가로서의 자긍심을 가질 수 있는 근무여건 조성이 필요하다고 강조하였다. 영유아가 어린이집 에서 생활하는 동안 가장 밀접한 상호작용의 주체가 보육교사 이기 때문에 이들이 자신의 권리실제를 어떻게 인지하느냐에 따라 보육활동의 질이 좌우될 수 있고, 이는 다시 영유아의 복 지에 영향을 미치게 된다. 이에, 영유아의 권리가 실현되기 위 해서는 어린집의 돌봄 주체인 보육교사들의 권리도 확보되어 야한다는 논리가 가능하다. 보육교사들이 안정적으로 권리를 확보하고 이를 사회적으로 인정받을 때 보육서비스의 질이 담 보되며, 영유아의 권리 향상으로 순조롭게 이어질 수 있기 때 문이다.

교사로서의 권리는 교사가 전문인으로서 자신의 직무를 수행할 수 있도록 법이 인정하는 지위와 역할을 말한다(D. R. Lee, 2016). 보육교사는 교사이면서 동시에 근로자이다. 보육 교사들의 권리확보 정도는 근로기준법에 명시되어 있는 근 로자로서의 법적(근무시간, 휴가사용 등)보호를 받지 못하 고 있는 것으로 나타났다(National Human Rights Commission [NHRC], 2012). 또, 유치원교사는 교육공무원법에 교사로서 의 법적 지위를 보장 받지만 보육교사는 그렇지 못하며, 영유 아보육법에서 보육교사의 권리는 매우 미흡한 실정이다.

최근 보육교사들의 권리에 관심을 보이는 움직임도 감지되 고 있다. 보육교사의 자격 강화와 함께 이들의 근무환경 및 처 우 개선 등을 함께 고려해야한다는 관련 학계의 주장이 그 예 가 될 수 있다. 이에 따라, 개정된 영유아보육법에는 보육교사 의 처우개선 조항도 포함됐다. 보육교사의 과중한 업무 부담
을 완화하기 위해 보조교사를 두는 규정이 신설되고, 휴가 또 는 보수교육 때 배치해야 하는 대체교사 관련 조항을 상향하 였다. 또한, 보육교사들의 권리에 대해 관련 연구도 시작되고 있다. Koo와 Jung (2016)이 보육교사와 유치원교사가 인식하 고 있는 교사의 권리에 대한 개념도를 분석하였다. 두 집단 모 두 교사 권리에 대한 지식이 다소 단편적이면서 분리적인 경 향을 보였는데, 보육교사들은 생활보장을 유치원교사들은 교 사인권을 가장 중요하게 인식하고 있었다. G. Kim (2016)은 유 치원교사와 보육교사의 권익 관련 법제도를 5 가지의 범주로 분석한 바 있다. 연구결과 “신분보장권 및 불체포특권’과 ‘전문 직으로서의 교육권 및 자율권'을 법적으로 보장받지 못하고 있는 것으로 드러났다. 위의 선행 연구들은 관련 법 분석이나 권리 개념을 파악하는 수준에 머무르는 한계를 지닌다. 실제 로 보육교사들이 자신의 권리를 어떻게 인식하고, 권리행사와 관련해 보육현장에서 어떠한 경험을 하는지를 충분히 분석하 지 못하고 있다. 보육교사들이 스스로 인식하고 체험하는 권 리가 어떠한지를 심층적으로 이해하기 위해서는 실증적 자료 를 바탕으로 이들의 경험 이면에 있는 복합적인 맥락을 함께 고려해야 할 것이다.

가정어린이집이란 개인이 가정 또는 그에 준하는 곳에 설 치·운영하는 어린이집으로, 상시 영유아 5 인 이상 20 인 이하 를 보육할 수 있는 어린이집이다(Child Welfare Act [CWA], Act No. 14086,2016$)$. 가정어린이집의 설립 배경은 1961 년 아동 복리법이 제정되면서 어린이집에 대한 법적 근거가 마련되었 다. 이후 1982년 유아교육진흥법이 제정되어 새마을 유아원 으로 명칭을 통일하게 된다. 그러나 새마을 유아원이 보육시 설로써의 기능을 못하자 가정보육시설이 자생적으로 생겨나 기 시작했다(Han, 1993). 현재 어린이집 현황을 살펴보면, 전 체 어린이집의 $50 \%$ 이상이 가정어린이집으로서 2015년도 기 준 총 42,517 개 중 22,074 개소에 이른다. 가정어린이집에서 종 사하는 보육교사의 수는 73,788 명으로 전체 보육교사 229,116 명 중 약 $32.3 \%$ 를 차지한다(KICCE, 2016). 가정어린이집이 보육 현장의 다수를 차지하며, 가정어린이집 보육교사들이 전 체 보육의 질에 미치는 영향은 그 중요성을 더하고 있다. 주지 할 점은 어린이집 유형에 따라 보육교사들의 근무환경 및 처 우가 다른데, 특히 가정어린이집의 근무환경이 가장 열악하다 는 점이다(G. S. Kim, Moon, \& Lee, 2015). 이에 본 연구에서는 어린이집 유형 중 상대적으로 근무환경이 열악하다고 평가되 는 가정어린이집 보육교사들을 대상으로 그들의 권리실제 경 험을 심층적으로 탐색하였다. 이를 통해 보육교사들의 권리실 제를 이해하고, 권리증진을 위해 개선되어야 할 방안을 모색 
하며, 궁극적으로 보육의 질을 향상시키는데 시사점을 주고자 하였다.

\section{연구방법}

본 연구에서는 해석학적 질적연구 방법(interpretive qualitative research)을 활용하였으며, 자료수집을 위해 FGI (Focus Group Interview) 방법을 활용하였다.

\section{연구참여자}

연구자는 평생교육원의 전문학사 과정에서 아동복지 수업을 맡고 있었으며, 아동권리 수업시간에 보육교사의 권리에 대 해 언급할 기회가 있었다. 수업 종료 후 연구참여자를 섭외하 기 위해 보육교사와 원장들을 대상으로 연구참여를 요청하였 고, 자발적 참여 의사를 밝힌 사람들을 표집하였다. 연구참여 자들은 모두 현재 고졸의 학력으로 가정어린이집에 종사하고 있는 공통성이 있다. 가장 열악한 배경과 환경적 특성을 갖고 있는 참여자들을 선정한 이유는 그들의 권리 또한 상대적으로 더 취약할 수 있다는 가정 때문이다. 본 연구의 주요 연구참여 자는 가정어린이집에서 종사하고 있는 보육교사 8 명이다. 모 두 보육교사교육원에서 보육교사 자격증을 취득하였으며, 고 졸의 학력으로 현재 전문학사 취득을 위해 평생교육원에서 영 유아보육을 전공하고 있다. 연구참여자들의 보육자격은 보육 교사 3 급 1 명, 2 급 2 명, 1 급 5 명이며, 보육경력은 1 년 이상 3 년 미만 2명, 3년 이상 5년 미만 2명, 5년 이상 4명이다. 담당 반 은 0 세에서 2 세 미만으로 모두 영아를 보육하고 있다.

본 연구의 두 번째 연구참여자 그룹은 가정어린이집을 운 영하고 있는 원장들이다. 원장들과 FGI를 실시한 목적은 가정 어린이집 보육교사들의 면접내용을 뒷받침하고 보육교사의 권리에 대한 상호관점을 포착하기 위해서이다. 본 연구참여 자 어린이집 원장들은 총 9명으로 어린이집 유형을 구체적으 로 살펴보면 민간 가정어린이집 8 명, 공공형 가정어린이집 1 명이다. 연구참여자 가정어린이집 원장들의 사회인구학적 특 성을 살펴보면 40대 4 명과 50대 5명이다. 모두 고졸의 학력으 로 보육교사교육원에서 보육교사 자격을 취득하였다. 어린이 집 원장 경력은 2년 이상 5년 미만 7명, 5년 이상 2명으로 나 타났다. 연구참여자들의 구체적인 특성은 Table 1에서 제시하 였다.

\section{자료수집}

본 연구에서는 가정어린이집 보육교사들이 보육활동을 수행 하는 과정에서 권리와 관련해 어떠한 경험을 하는지 탐색하 기 위해 포커스그룹 방법을 활용하였다. 포커스그룹의 특성은 다음과 같다. 첫째, 포커스그룹은 구체적인 주제에 대한 자료 를 모으는데 집중하게 되는 특별한 집단으로, 유사한 경험을 가진 집단이 모여 경험과 의견을 나눈다(Schwandt, 2007). 본 연구참여자 집단은 가정어린이집 보육교사로서 보육활동 수 행이라는 경험을 공유하고 있어 '보육교사의 권리'라는 주제 에 대해 집중적인 대화를 만들어 낼 수 있다. 둘째, 참여자들은 타인의 이야기를 통해 자신의 경험을 탐구하고 발견하게 된 다. 그룹 토론을 통해 주제에 대한 깊이 있는 이해와 통찰을 갖 게 되고 자신의 견해를 통해 풍부한 이야기를 생성하게 된다 (David, 1997). 특히, 본 연구참여자들은 교사권리에 대한 인식 이 약한 특성이 있는데 개별 면접보다 포커스 그룹 면접 방법 은 참여자들의 인지적인 활동을 활성화 시키는데 유용하다.

본 연구를 위한 예비조사로 자료를 수집하기 전에 가정어 린이집 보육교사와 원장 각 1 명에게 본 연구내용을 설명하고 질문내용을 검토 받았다. 이 과정에서 연구참여자들이 보육교 사의 권리에 대해 어떻게 인식하고 있는지 파악할 수 있었으 며, 면접 질문내용을 보완할 수 있었다. 주요 면접질문은 “보 육교사의 권리가 무엇이라고 생각하는가?”, “보육업무를 수행 하는 과정에서 권리실제와 관련해 어떠한 경험을 했는가?”이 다. 자료수집에서 질적연구 방법의 순환적 과정에 따라 새로 운 면접내용을 추가로 보완해 나갔다. 연구윤리 준수를 위해 자료수집 전 참여자들에게 연구목적과 개요에 대해 설명을 하 고 자발적 참여 의사를 확인 후 연구참여 동의서를 받았다. 또, 면접 내용은 녹음될 것이며, 면접 도중 연구참여를 철회할 수 있다는 것을 고지하였다. 연구참여의 답례로 소정의 기념품을 제공하였다.

본 연구에서는 가정어린이집 보육교사 2그룹(각 그룹에 4 명, 총 8 명)과 가정어린이집 원장 2그룹(4명 1그룹, 5 명 1 그룹, 총9명)으로 총 4 번의 FGI를 실시하였다. 면접은 평생교육원 측의 양해를 얻어 빈 강의실에서 진행되었다. 본격적인 포커 스 그룹 면접을 실시하기 전 연구자는 참여자들과 사전 만남 을 통해 라포를 형성하였다. 사전 미팅 시 연구개요에 대해 설 명하자 참여자들은 연구목적과 활용에 대해 질문을 하였고 연 구자는 참여자들의 알 권리를 보장하기 위해 자세하게 설명을 제공하였다. 총 4 회의 면접에서는 자료수집을 위한 본격적인 면접이 이루어졌다. 보육교사와 원장들 간의 그룹을 구분지어 
Table 1

Characteristics of Participants

\begin{tabular}{|c|c|c|c|c|c|c|c|c|}
\hline No. & Gender & Age & Grade & $\begin{array}{c}\text { Career } \\
(\mathrm{yr})\end{array}$ & $\begin{array}{l}\text { Qualifications } \\
\text { (grade) }\end{array}$ & Certifying institutions & $\begin{array}{c}\text { Types of daycare } \\
\text { center }\end{array}$ & Age class \\
\hline \multicolumn{9}{|c|}{ Child care teacher } \\
\hline 2 & Female & 47 & High school & 6 & $\begin{array}{l}\text { Child care } \\
\text { teacher } 1\end{array}$ & $\begin{array}{l}\text { Child care teacher } \\
\text { education }\end{array}$ & $\begin{array}{c}\text { Home daycare } \\
\text { centers }\end{array}$ & 1 \\
\hline 4 & Female & 49 & High school & 5 & $\begin{array}{l}\text { Child care } \\
\text { teacher } 1\end{array}$ & $\begin{array}{c}\text { Child care teacher } \\
\text { education }\end{array}$ & $\begin{array}{l}\text { Home daycare } \\
\text { centers }\end{array}$ & 2 \\
\hline 5 & Female & 46 & High school & 2 & $\begin{array}{l}\text { Child care } \\
\text { teacher } 2\end{array}$ & $\begin{array}{l}\text { Child care teacher } \\
\text { education }\end{array}$ & $\begin{array}{l}\text { Home daycare } \\
\text { centers }\end{array}$ & 1 \\
\hline 8 & Female & 46 & High school & 4 & $\begin{array}{l}\text { Child care } \\
\text { teacher } 1\end{array}$ & $\begin{array}{c}\text { Child care teacher } \\
\text { education }\end{array}$ & $\begin{array}{c}\text { Home daycare } \\
\text { centers }\end{array}$ & 1 \\
\hline \multicolumn{9}{|c|}{$\begin{array}{l}\text { Director of daycare } \\
\text { centers }\end{array}$} \\
\hline 1 & Female & 45 & High school & 2 & $\begin{array}{l}\text { Child care } \\
\text { teacher } 1\end{array}$ & $\begin{array}{l}\text { Child care teacher } \\
\text { education }\end{array}$ & $\begin{array}{c}\text { Home daycare } \\
\text { centers }\end{array}$ & 1 \\
\hline 2 & Female & 58 & High school & 6 & $\begin{array}{l}\text { Child care } \\
\text { teacher } 1\end{array}$ & $\begin{array}{c}\text { Child care teacher } \\
\text { education }\end{array}$ & $\begin{array}{c}\text { Home daycare } \\
\text { centers }\end{array}$ & 0 \\
\hline 3 & Female & 54 & High school & 2 & $\begin{array}{l}\text { Child care } \\
\text { teacher } 1\end{array}$ & $\begin{array}{c}\text { Child care teacher } \\
\text { education }\end{array}$ & $\begin{array}{c}\text { Home daycare } \\
\text { centers }\end{array}$ & 1 \\
\hline 6 & Female & 42 & High school & 1 & $\begin{array}{l}\text { Child care } \\
\text { teacher } 1\end{array}$ & $\begin{array}{c}\text { Child care teacher } \\
\text { education }\end{array}$ & $\begin{array}{l}\text { Home daycare } \\
\text { centers }\end{array}$ & 0 \\
\hline 7 & Female & 50 & High school & 3 & $\begin{array}{l}\text { Child care } \\
\text { teacher } 1\end{array}$ & $\begin{array}{c}\text { Child care teacher } \\
\text { education }\end{array}$ & $\begin{array}{c}\text { Home daycare } \\
\text { centers }\end{array}$ & 1 \\
\hline 8 & Female & 53 & High school & 2 & $\begin{array}{l}\text { Child care } \\
\text { teacher } 1\end{array}$ & $\begin{array}{c}\text { Child care teacher } \\
\text { education }\end{array}$ & $\begin{array}{l}\text { Home daycare } \\
\text { centers }\end{array}$ & 1 \\
\hline 9 & Female & 50 & High school & 2 & $\begin{array}{l}\text { Child care } \\
\text { teacher } 1\end{array}$ & $\begin{array}{l}\text { Child care teacher } \\
\text { education }\end{array}$ & $\begin{array}{l}\text { Home daycare } \\
\text { centers }\end{array}$ & 1 \\
\hline
\end{tabular}

면접을 실시한 이유는 연구주제가 보육교사의 권리에 관한 것 으로 권리의 주체가 아닌 원장들과는 입장이 다를 수 있고, 무 엇보다 보육업무를 수행하는 과정에서의 경험들을 자유롭게 이야기할 수 있는 분위기를 조성하기 위해서이다. 실제로 연 구결과 보육교사의 권리에 대해 합치되는 내용도 있었지만 보
육교사와 원장들 간에 상이한 관점이 포착되었다.

\section{자료분석}

연구자들은 자료분석 시 연구자 간의 합의적 결과를 도출하기 
위해 지속적인 비교분석과 논의를 이루어나갔다. 특히, 본 연 구는 비판적 사회과학으로 연구참여자들을 옹호하는 입장을 취했으나 객관적이고 실증적인 자료에 근거한 해석을 이루고 자 노력하였다. 수집된 자료는 그룹내분석(group level analysis) 을 통해 의미단위를 도출한 후, 그룹간분석(across-analysis comparison)을 통해 중심 주제를 구조화하였다. 먼저, 그룹내 전사 자료를 해체하여 공통적으로 발견되는 의미단위(단어, 구, 문장)를 도출하였다. 이 과정에서 상반되는 내용이나 예외 적 사례(negative case)들은 따로 분리하여 최종 결과와 다시 비 교를 이루었다. 다음은 그룹별로 자료를 비교 분석하였는데, 보육교사들 그룹과 원장들 그룹의 자료를 비교분석하는 과 정에서 상호 관점과 현상에 대한 맥락을 이해할 수 있는 실증 적 자료들을 도출할 수 있었다. 자료분석 시 타당화 확보를 위 해 첫째, 자료를 분석하는 과정에서 범주를 분류하고 중심 주 제 도출 시 연구자 간의 일치를 지속적으로 확인하는 다원화 (analytic triangulation)를 이루었다. 둘째, 아동학을 전공한 동 료지지집단(peer support group)으로부터 자료와 해석의 타당 성 여부에 대한 의견을 구했다.

\section{연구결과}

본 연구에서는 가정어린이집 보육교사들이 교사로서 자신의 권리를 어떻게 인식하고 있으며, 권리실제와 관련해 보육현 장에서 어떠한 경험을 하는지 탐색하였다. 본 연구가 가정어 린이집을 선택함으로써 가정어린이집 보육교사들의 특수성 을 반영하고 있지만 다른 형태의 어린이집에 종사하는 보육 교사의 특성과 연계되어지는 부분들이 있다. 따라서 다른 어 린이집 보육교사들과의 괴리된 경험이 아니고 그들과 공통적 인 경험이 있음으로 연구결과를 그들에게까지 적용할 수 있 을 것이다.

연구결과 가정어린이집 보육교사들은 교사로서 자신들의 권리실현이 잘 이루어지지 않고 있다고 인식하고 있었다. 구 체적으로 살펴보면 첫째, 교사-원장 간 상호관계에서는 전문 가로서의 자율권 및 근로자로서 고용보장이 취약한 것으로 드 러났다. 둘째, 영유아보육법 및 보육관련 제도에서 원장담임 겸직제도, CCTV 설치규정 등과 관련해 권리확보에 어려움을 겪고 있었다. 셋째, 전문가로 인정하지 않는 사회적 인식도 보 육교사의 권리실현에 부정적인 영향을 미치고 있었다. 한편, 연구참여자들은 보육교사로서 취약한 권리를 향상시키기 위 해 다양한 노력을 수행하고 있었다.

\section{교사-원장 간 상호관계에서의 권리}

연구참여자 가정어린이집 보육교사들은 원장과의 상호 관계 에서 교사로서 권리를 보호받지 못한다고 생각하고 있었는데 구체적으로 살펴보면 다음과 같다. 첫째, 전문가로서 자율권 을 보호받지 못한다고 느끼고 있었다. 가정어린이집에서는 가 정이라는 소규모 공간에서 보육교사들의 업무가 수행되는 특 성으로 원장-교사 간의 관계가 밀접하고 상호작용이 빈번하 게 발생된다. 가정어린이집에서 보육교사의 보육활동은 물론 이고 학부모와의 상호작용, 기타 행정 업무 등 대부분의 보육 일과가 원장의 시야에 노출된다. 이 때 원장은 보육교사의 활 동에 관여를 하게 되는 것으로 나타났다. 보육교사들은 원장 의 관여로 자신들의 보육활동을 소신대로 실행하는데 있어 제 약을 경험하고 있었다.

원장님이 자기 스타일로, 자기가 알고 있는 걸로 끌고 가 려고 하시더라고요. 그래서 저도 그만 뒸어요. 저 같은 경우는 배운 게 있고 애를 어떻게 케어를 해야 하는 게 있잖아요. 울더라도 그치게끔 기다려주고 내가 놀아주 는 스타일이거든요. 근데 그 순간 원장님은 애가 우는 걸 못 보시는 거예요. 단 몇 분간을 못 보시는 거예요. 바로 개입해서 딱 업고 가버리시고. 그럼 이 아이가 나에게 적 응되기 까지가 길어지는 거예요. (연구참여자 \#07)

제가 아이들을 다 케어를 할 수 있는데, 재는 왜 이렇게 하니 재는 왜 이렇게 하니 간섭을 해버리니까 이게 혼돈 이 와요. 나는 내 방법이 있는데 원장님이 들어와서 갑자 기 이렇게 해버리면 애한테 미안한 거 있잖아요. (연구대 상자 \#08)

특히, 학부모-보육교사와의 관계에서 원장의 개입이 이루 어지고 있었는데, 담임을 맡고 있는 보육교사보다 원장이 어 머니와 더 밀접하게 상호작용하고 있었다. 보육교사들은 학부 모와의 상담에서 원장이 주도하기 때문에 자신들은 배제되기 도 하고, 보육과정에서 나타나는 영유아의 생활습관이나 행동 과 관련해 어머니에게 솔직하고 세밀한 정보를 제공하지 못한 다고 이야기하였다. 보육교사들은 발달과정에서 나타나는 언 어, 행동, 습관 등에 있어 긍정적, 부정적인 특성들을 어머니와 의견을 교환하고 함께 협력하여 긍정적인 발달을 도모하고자 하나 원장들은 영유아에 관한 부정적인 이야기를 어머니에게 전달하는 것을 제한하고 있었다. 이는 가정어린이집의 경우 
원아 모집이 경영과 밀접하게 연관되어 있기 때문에 원장들은 어머니에게 자녀의 어립이집 생활에 대해 긍정적인 면을 부각 시켜 강조하고 있는 것으로 나타났다.

엄마한테 아이에 대해 솔직하게 애기를 해줬으면 좋겠 는데, 엄마가 어린이집을 그만둘까봐 아이에 대해 미화 시키는 거죠. 사실을 말하고 싶고 상담을 해서 좋은 방향 으로 나갈 수도 있는 거잖아요. 그런 거를 애기하면 엄마 는 원에 문제가 있다고 생각하기도 하고, 아이를 안 보낼 수도 있겠죠. 그래서 원장님은 그런 걸 빼고 아이의 잘하 는 부분만 애기를 하길 바라고, 그런 말 하지 말라 이런 식으로 말씀하시죠. (연구참여자 \#02)

제대로 연계가 안 돼요. 부모하고 나하고 다이렉트로 제 대로 안 돼요. 원장이 자기가 개입을 하려고 하니까 그런 문제가 있어요. (연구참여자\#07)

본 연구에 참여한 가정어린이집 원장들은 어머니들과의 긍 정적인 관계형성을 중요하게 인식하고 있었다. 가정어린이집 원장들이 부모와의 관계에 특별히 관심을 갖는 이면에는 보육 교사들이 지적한 것과 같이 원아모집이 중요한 요인으로 작용 하고 있었다. 보육서비스를 받는 대상은 영유아지만 선택은 어머니들이 하기 때문에 소비자인 어머니들의 욕구에 부합하 게 된다. 또한, 가정어린이집의 경우 원아 모집은 예산 지원과 직접적으로 연관되며, 재정은 어린이집 운영에 지대한 영향을 미치기 때문이다.

아이들 케어 문제에서는 본인이 스스로 보육교사들이 알아서 하지만 엄마 관계에서는 원장이 같이 개입이 되 어야.. 왜 그러냐면 전체적인 면에 돌아가는 거는 가정이 다 보니까 원장이 알아야 되니까. (원장 \#09)

원아모집을 잘 해야 되지 원장이니까. 원아모집을 일단 해야 되고 운영자니까 엄마들과의 관계들도 원활하게 잘 소통해야 하는 거고. (원장 \#04)

둘째, 가정어린이집 보육교사들은 근로자로서 고용보장이 매우 취약한 것으로 드러났다. 실제로 본 연구참여자 가정어 린이집 보육교사들은 불안정한 고용상황에 놓여 있었는데, 원 아모집에 있어 정원이 채워지지 않으면 자신의 의사와 상관없 이 어린이집을 그만 두는 일이 빈번하게 발생하고 있었다. 원
아 미달 시 재정적인 어려움으로 급여를 보장받지 못한다는 사실을 잘 알고 있기 때문에 보육교사들은 해고를 어쩔 수 없 이 수용해야 한다고 토로하였다. 가정어린이집 보육교사들은 자신들의 신분보장권이 취약하다는 것을 잘 인지하고 있었다. 하지만 소규모의 가정어린이집은 원아모집이 어린이집의 재 정 결정과 보육교사의 인건비를 확보하는 중요한 요인으로 작 용하고 있는 상황에서 자신들의 신분보장을 주장하기에는 한 계가 있었다.

가정 어린이집 같은 경우에는 인원이 딱 채워지면 좋은 데요, 세 명 원장님까지 네 명의 보육교사가 있다가 인원 이 안 채워졌어요. 그러면 '아 이제 나는 잘리는 구나.' 이 거 있어요. 불안한 게 아니라 그만 뒤야 돼. 왜냐하면 수 입이 안 되니까는 누군가 하나는 빠져야 하는데 그게 있 어요. (연구참여자\#05)

원장의 권한에 따라 보육교사들이 일을 그만 두게 되는 관 행은 고용을 보장 받지 못하는 차원에 머무르지 않고 있었다. 불안정한 고용상황은 보육교사들의 업무수행에도 영향을 미치 고 있었는데, 자신의 의견이 합리적이고 정당하더라도 원장에 게 주장을 하거나 권리를 확보하기 위한 행동을 할 수 없는 상 황으로 이어지고 있었다. 가정어린이집에서는 보육교사의 고 용과 해고에 대한 주도권을 원장이 갖고 있기 때문에 원장과의 마찰이 고용유지에 부정적으로 작용할 수 있기 때문이다.

그게 왜냐면 저희 같은 경우에는 한 곳에 오래 상주하고 싶어도 이제 원장님이 맞지 않는다는 이유로 그만 같이 일하기가 힘들다고 하시면 저희는 새로운 곳을 찾아야 하니까... (연구참여자 \#03)

가정어린이집 보육교사들이 고용을 보장받지 못하고 있는 부분에 대해 원장들도 현실적으로 정원이 충족되지 못하면 가 정어린이집 운영에 재정적으로 타격을 받기 때문에 어쩔 수 없이 보육교사를 해고해야 하는 상황이 벌어져 안타깝다는 심 정을 토로하였다. 본 연구에 참여한 일부 원장들은 보육교사 해고를 막기 위한 다른 대안을 모색하기도 했는데, 보육교사 들의 동의를 얻어 급여의 일정부분을 삭감하거나 몇 달로 나 누어 분할지급을 했던 것으로 드러났다. 일부 가정어린이집 원장들은 보육교사의 급여삭감이나 분할지급이 운영자로서 양심의 가책을 느낄 뿐만 아니라 편법이라는 사실을 잘 알고 있지만 보육교사를 해고하는 것 보다 낫기 때문에 어쩔 수 없 
는 선택이라고 토로하였다.

이 선생님을 그만두게 할 수 없으니까 교사가 3명이 있 어요. 그러면 이 선생님 월급을 다 못 주잖아요. 그러니 까 선생님도 예를 들어서 20 만원 삭감. 이 선생님도 20 만원 삭감. 나도 20 만원 삭감. 그러고 원장은 어느 정도 마이너스 보고. 이 선생님이 만약에 100 만원이에요 그럼 선생님 3 명이서 20 만원씩 줄이는 거예요. 그 대신 일찍 가는 거야. 이 선생님 데리고 있고. 이런 부분들이 상당 히... (원장 \#04)

\section{영유아보육법 및 보육정책에서의 권리}

본 연구에서는 보육정책 및 관련 제도는 보육교사들의 권리를 보호해 주지 못하는 것으로 나타났다. 첫째, 원장담임 겸직 제 도로 인해 보육교사들은 담당아동 이외에 초과보육을 수행하 고 있었다. 가정어린이집은 원장이 담임을 맡을 수 있기 때문 에 대부분의 가정어린이집 원장은 보육과 운영역할을 함께 수 행하고 있다. 원장직무 수행 시 담당 반의 영유아 보육을 보육 교사들이 나누어 맡고 있었다. 결과적으로 보육교사들은 자 신이 맡은 담당 반의 영유아와 원장 반의 영유아를 함께 보육 하기 때문에 초과보육을 수행하게 된다. 문제는 보육교사들이 원장 반 영유아를 함께 맡음으로 발생되는 초과보육이 단시간 의 일회성이 아니라 일반적으로 지속해서 발생하고 있다는 것 이다.

아동 비율이 $1: 3,1: 5$ 잖아요. 가정어린이집에서는 원장 님도 반을 맡으시잖아요. 그러면 원장님 반으로 안 하고, 요쪽 반으로 한명 요쪽으로 한명 나눠서 교사한테 부담 을 시키잖아요. 제대로 된 비율이면 그 아동을 잘 케어 할 수 있는데 이쪽 반 데려다 놓고 이쪽 반 데려다 놓으 면... 거의 가정어린이집 원장님은 반을 맡을 뿐이지 실 제로 안 하세요. 그게 전부 개선이 되어야 할 문제에요. (연구참여자 \#02)

저희는 1 명씩 다 나눠서 봐요. 제가 작년에 원장님반 애 를 맡았어요. 처음에는 애들이 3명이었어요. 그럼 1 대 3 맞잖아요. 그러더니 원장님 이름으로 올라간 애가 또 와 요. 한명 또 와요. 그럼 5명이에요. 그럼 초과잖아요. 원 장님은 딴 거 하시느라고 저희 교실을 안 들어와요. 그럼 저 혼자 그걸 다 보는 거예요. (연구참여자 \#08)
본 연구결과 연구참여자 가정어린이집 보육교사들이 공통 적으로 지적한 가장 큰 문제점은 원장담임 겸직 제도로 인한 초과보육이었다. 이는 보육교사들에게 업무부담으로 인해 과 도한 스트레스를 유발하기도 하지만 영유아에게 직접적인 영 향을 미치기 때문이다. 초과보육 영유아의 수만큼 보육교사 의 역할이 나누어지기 때문에 제대로 생활지도를 할 수 없을 뿐만 아니라 세심하게 보육을 제공하는데 어려움이 발생되고 있었다. B. J. Kang과 Kim (2014)이 수행한 연구에서 보육교사 의 정서노동은 영유아권리존중 보육의 관계에서 유의미한 상 관이 있는 것으로 나타났다. 대부분의 보육교사들은 초과보육 수행에 대한 심리적 스트레스를 받고 있었으며, 이는 결과적 으로 아동의 영유아권리에도 영향을 미치게 된다.

가정 어린이집은 원장님이 담임을 해도 되는 시스템이 니까, 수입 지출을 그게 아니고는 맞출 수가 없으니까 원 장님들이 담임을 맡는데 그 행정 업무라든지 주방 일이 라든지 할 수가 없더라구요. 저희 같은 경우는 5명은 제 가 보고 원장님 반은 지금 2 명이에요. 근데 애들이 적응 이 잘 안 이루어지더라구요. 이게 기본 생활이 안 잡히고 많이 흐트러지더라구요. (연구참여자 \#05)

원장님 반까지 제가 케어를 하다 보니까 이제 힘도 들고 애들한테 사랑도 그만큼 못줘요. 일하면서도 내가 3 명만 우리 반만 맡으면 되는데 왜 애까지 내가 해야 하나? 하 는 생각이... 이런 감정이 쭉 올라가는 경우가 있거든요. 그럼 누르고 에이 해야지 하는 것도 있는데, 이건 진짜 개선이 되어야 할 거 같고요. (연구참여자 \#01)

본 연구참여자 대부분의 가정어린이집 원장들도 담임겸직 제도로 인해 보육교사들의 업무가 가중되어 어려움을 겪고 있 다는 것을 인정하고 있었다. 하지만 원장은 담당 반 영유아의 보육뿐만 아니라 간식준비, 상담, 운전, 행정업무 등을 수행해 야하기 때문에 보육교사들에게 부담을 줄 수밖에 없다고 토로 하였다.

가정어린이집 같은 경우에는 우리가 반 맡는 거로 허용이 되니까 다 맡고 있고... 저 같은 경우는 보조교사가 2 시까지는 보고, 그 이후부터 제가 보는데... 우리가 애만 볼 수 있는 상황 이 아니잖아요. 학부모님들 상담도 오고, 그런 게 좋아지지는 않을 거 같아요. 특별한 정책이 없는 한은. (원장 \#05)

둘째, 아동학대를 예방하기 위해 마련된 CCTV 설치로 인 
해 보육교사들은 보육활동에 제한을 경험하고 있었다. 특히 생활습관이 형성되는 시기로 훈육이 필요한 상황이 발생하게 되는데 CCTV를 의식하게 되어 필요한 훈육을 포기하는 것이 다. 보육교사의 행동이 사실과 다르게 왜곡되어 CCTV에서 보여 질 수 있기 때문에 영유아의 팔이나 몸을 잡거나 하이파 이브 같이 손을 움직이는 행동에 있어 민감하게 의식할 수밖 에 없다는 것이다. 아동학대와 같은 불필요한 오해 상황을 만 들지 않기 위해 보육교사들은 소극적으로 보육활동을 수행할 수밖에 없다고 토로하였다.

기본생활이라던가 좀 고쳤으면 좋겠는데도 그거에 의해 서 오히려 못하고 그냥 어쩔 수 없이 애가 잘못했어도 그 냥 안고 달래고 이런 식으로... (연구참여자\#01)

하이파이브 같은 것도 (손이)서로 나가잖아요. 근데 CCTV에서 이게 때리는 것처럼 보이나봐요. (연구참여 자 \#06)

훈육할 때 아이를 잡으면서도 아 여기서 잡으면 저기서 (CCTV) 세게 보이겠지 그냥 또, 아 여기 CCTV 있지 생 각하면 먹어볼래? 하다가 안 먹으면 버려요. 내 아이, 우 리 아이 먹이듯이 하는 것은 이제 다 사라진 거예요. 그 거 때문에 CCTV에서는 강제로 보여 질 수 있으니까 그 냥안 먹여요. (연구참여자 \#08)

본 연구참여자 가정어린이집 보육교사들은 CCTV와 관련 해 보육활동에 제한을 받을 뿐만 아니라 자신의 동의 없이 언 제든 열람할 수 있는 상황이 발생하는 것에 대해 자신의 일에 관한 의사결정 권리가 취약하다고 느끼고 있었다. 연구참여자 (\#04)는 부모에게 아동학대 오해를 받게 되는 상황이 발생했 을 때 원장과 학부모가 CCTV를 열람한 사실을 나중에 알게 되었다고 이야기하였다. 이 때 보육교사의 권리를 보호해 주 어야 할 원장이 학부모의 입장에서만 일을 처리하고 보육교사 인 자신의 의견과 입장을 전혀 옹호해 주지 못했다라고 판단 하고 있었다. 이전에는 부모와 교사 간에 대화로 오해를 풀고 이해시키는 과정이 있었는데, CCTV 설치 후 어머니들은 사 소한 일에 과민반응을 보이며 CCTV 열람을 요구하는 상황이 자주 발생하고 있었다. 어머니들은 어린이집에서 발생한 문제 에 있어 일차적으로 보육교사에게 의논하지 않고 있었는데, 보육교사 당사자들은 자신이 수행한 직무활동 확인과정에서 배제됨은 물론이고 신뢰를 전제로 해야 하는 어머니와의 관계
에서도 어려움을 겪고 있었다.

학부모하고의 믿음도 깨지는 거 같아요. (연구참여자 \#02)

제가 일과를 애기 해주어 그 말을 신뢰할 줄 알았어요. 너무나 놀란 게 CCTV를 돌려본 거예요. 원에 와서 원장 님하고 온 가족이. 아침에 출근을 했을 때 그 밤중에 온 식구가 나와서 CCTV를 들여다봤다는 소리에 속상한 거예요. 어머니한테 대변할 수 있는 문제인데 무조건 와 서 보고 나중에 애기를 하는 거예요. 선생님 CCTV 한번 돌려볼 수 있겠냐고 이런 말 한마디도 없이 단도직입적 으로... (연구참여자 \#04)

셋째, 가정어린이집 보육교사들은 근로자로서 휴가사용에 있어 제한을 받고 있었다. 본 연구결과 가정어린이집 보육교 사들이 휴가사용에 있어 상당한 제한을 받는 것으로 나타났는 데, 휴가를 사용하게 되면 담당 반의 영유아를 대신 보육해 줄 대체교사가 부재하기 때문이다. 본 연구에 참여한 대부분의 가정어린이집 보육교사들은 월차나 병가를 사용한 적이 거의 없었고, 아파도 출근해서 어린이집에 와서 누워서 애들을 돌 보았다(\#07)고 토로하였다. 가정어린이집에서 근무하고 있는 보육교사들의 휴가는 제도로써 명목상 존재하고 있지만 실질 적으로 거의 사용되지 못하고 있었다. 영유아를 돌보는 보육 교사들의 휴가사용 제한은 소진으로 이어질 수 있는데, 보육 교사의 업무소진은 보육활동의 질을 저하시키게 된다. 특히, 가정어린이집은 영아의 이용률이 높은 특성이 있어 교사의 심 리적, 신체적 건강성은 중요하다.

근데 정말 보육 교사는 월차 제도는 꼭 하나는 있어야 될 거 같아요. 사람인데 그래도 한 달에 한번은... (연구참여 자 \#05)

아파도 어린이집에서 아파야 해요. 눈치를 주니까 아예 안 쉬는 거죠 아파도. 없어요. 그런 거 전혀 없어요. (연구 참여자 \#06)

넷째, 가정어린이집 보육교사들은 급여 및 경력 산정에 있 어 체계가 미흡하기 때문에 낮은 처우는 물론이고 경력이 반 영되지 않고 있어 더욱 열악한 상황에 있었다. 국공립이나 민 간 어린이집 같은 경우 대부분이 급여체계에 있어 호봉제를 
적용하고 있다. 또한 보육교사의 경력이 급여산정에 반영되기 때문에 경력이 쌓일수록 급여도 보장을 받게 된다. 하지만 가 정어린이집의 경우 현실적으로 급여체계에 적용을 받을 수 없 어 저임금에 머물러 있게 된다.

임금 문제에서 이제 막 근무한 사람이던, 5년 6년 10년 일하던 사람이던 똑같잖아요. 이런 것도 저는 개선이 되 어야 한다고 생각을 해요. (경력, 경력 그렇지) 경력에 대 한 거. (연구참여자 \#02)

본 연구참여자 가정어린이집 원장들도 보육교사들의 처우 가 낮다는 것에 동의하고 있었다. 특히, 경력이 쌓여도 급여를 올려주지 못하는 부분에 대해 안타까운 마음을 토로하였다. 원장(\#04)은 가정어린이집 보육교사들의 급여에 경력이 반영 되지 못하고 있으며, 국가에서 매년 정하는 최저임금의 상승 만큼 인상되고 있다고 이야기하였다. 또한, 원장들은 보육교 사들의 보육활동에 대해 높은 노동 강도를 동반한다고 보고 있었다. 보육교사들은 근무시간 동안 전혀 개인적인 휴식시간 을 활용하지 못하고 있었는데 잠깐 이라도 아이들에게서 눈을 떼면 안전사고로 이어지기 때문이다. 원장들은 가정어린이집 보육교사들의 근무환경이 열악하고, 정신적, 육체적으로 강도 높은 노동을 수행하고 있다는 것을 인정하지만 현실적으로 급 여를 보장해 주지 못하는 것으로 나타났다.

최저임금이 오르면 그만큼만 오르거든요. 중소기업에만 다녀도 급여가 1년이면 얼마씩 오르는데 보육시설에 있 는 선생님들은 최저임금밖에 안 오르니까 그런 부분에 서 힘들 거 같아요. (원장 \#04)

민간이나 국공립은 호봉 수는 인정해줘서 어떻게 원장 권한으로 올려줄 수는 있어도 저희는 올려줄 수 있는 여 력이 없어요. 어린이집 오래했다고 운영비를 더 주는 건 아니거든요. 10 년이 되나 1 년이 되나 월급 둘 다 똑같아 요. 항상 미안해 이렇게 밖에 못 주겠다 라면서 줘요. 월 급에 있어서 항상 미안한 마음은 갖고 있어요. 왜냐면 이 게 쉬운 직업은 아니거든요. 그게 정신노동이면서도 감 정노동이라고나 할 수도 있는 부분들 굉장히 커요. (원장 \#08)

육체적으로 힘들고 쉬는 시간도 거의 쉴 수가 없잖아요. 아이 옆에 항상 있어야 되고. 그런데 급여 부분에서도 그
렇죠. 본인이 일하신 만큼 본인이 받아가지 못하시니까. (원장 \#06)

\section{전문가로 인정하지 않는 사회적 인식}

연구참여자 가정어린이집 보육교사들은 어린이집을 이용 하고 있는 어머니들이 자신들을 교사나 전문가로 인정하기보 다 아이를 돌봐주는 '보호모'로 낮게 평가하고 있다고 이야기 하였다. 가정어린이집 교사들은 영아반 보육교사의 역할로 안 전, 위생, 돌봄, 교육이 포함되며, 특히 영유아의 위생관리에 세심하게 주의를 기울여야 한다는 것을 잘 인지하고 있었다. 하지만 가정어린이집을 이용하는 대부분의 어머니들은 보육 교사의 여러 역할 중 전문가로서 수행하는 교육활동이나 언어 및 발달과 관련된 부분에 대해서는 언급하지 않고 돌봄에만 초점을 두고 있는 것으로 나타났다. 가정에서 어머니들이 수 행해야 하는 위생부분을 지나치게 보육교사에게 요구할 경우 보육교사들은 어머니들이 자신들을 전문성을 가진 교사가 아 닌 단지 돌봄 제공자로만 대하고 있다고 느끼고 있었다.

교사가 아닌 그냥 보호모. 등원이나 이런 거 할 때 그 아 이의 위생상태가 안 좋잖아요. 양치를 해주세요. 이런 개 인적인 위생 관리까지 교사들한테 해달라고 하는 그런 학부형들이 있어요. 그런 거 보면 진짜... 진짜(웃음) 개 인적인 돌봄이 인거에요. 교사가 아니고... 그런 사례도 되게 많았던 거 같아요. (연구참여자 \#03)

권리가 없는 거 같아요. 엄마들은, 교사들은 그냥 와서 애 봐주는 사람으로만 생각하고 있는 그런 느낌. (연구참 여자 \#08)

본 연구참여자 가정어린이집 보육교사들은 어머니들이 영 유아의 위생이나 안전과 같은 기본생활보다 교육활동이나 발 달과 관련된 전문적인 부분에 대해 언급해 주기를 기대하고 있었다. 이는 가정어린이집 보육교사들이 어머니들로부터 전 문성을 가진 교사로 인정받기를 원하는 것으로 해석된다.

엄마들이 보육과정에 대해 실질적으로 '이런 거 해 주세 요.'하면 좋은데, 그런 거는 전혀 아니고... 진짜 케어, 기 저귀 발진 같은 이야기가 더 많은 게 가정 어린이집 인거 같아요. (연구참여자 \#02)

그게 계속 반복되니까 문제더라고요. 세수를 안 하고 오 
는 애는 계속 안 하고 와요. 근데 그게 어느 선에서 끊어 졌으면 좋겠는데, 그런 말 하는 거 자체를 못 하게 하니 까. (연구참여자 \#04)

가정어린이집을 이용하는 어머니들이 보육교사를 전문성 을 가진 교사로 인정하기보다 단지 돌봄 제공자로 인식하고 있다는 것에 원장들도 같은 입장을 보이고 있었다. 또한, 원장 들은 어머니들의 태도나 요구사항에 있어 가정어린이집을 전 문기관으로 인정하지 않고 있다고 느끼고 있었다.

저기 이제 특히 가정 어린이집 그러면은 그냥 애 봐주는 기관 이렇게 생각을 밑바탕에 깔고 하기 때문에... (원장 \#02)

현재 학부모들은 보육교사를 하나의 선생님으로, 전문 가로 생각을 안하구요. 그냥 우리아이 케어해주시는 돌 봄이로... 실질적으로 선생님한테도 애기하는 게 그거에 요. 우리아이 아침에 등원할 때 밥 안 먹었어요. 밥 많이 먹여 주세요. 보육교사는 그냥 교육원에서 1 년 다닌 그 런 쪽으로만... 인터넷이 발달돼서 젊은 어머님들이 너무 잘 아세요. 그렇기 때문에 보육교사를 전문가로 보진 않 아요. (원장 \#08)

또한, 본 연구참여자 대부분의 가정어린이집 보육교사들은 보육교사라는 직업이 사회적으로 인정받지 못하고 있다고 이 야기하였다. 특히, 유치원에 종사하는 유치원교사와 보육교사 간의 사회적 인식이 차별화 되어 있다고 느끼고 있었다. 보육 교사는 누구나 할 수 있는 일반적인 직업인데 비해 상대적으 로 유치원교사는 교사로서 사회적인 인정과 존경을 받고 있다 고 이야기하였다.

그냥 너도 보육교사야 나도 보육교사야 그런 거잖아요. 동네 아줌마들이 할 일 없어서 보육교사 보육원 나와 가 지고 이런 식으로... (연구참여자\#02)

보육교사하고 유치원교사하고 사람들의 선입관이라고 나 할까요. (연구참여자 \#06)

유치원교사는 진짜 유치원교사로 보고 어린이집은 그냥 누구나 할 수 있는... (연구참여자 \#08)

연구참여자들은 가정어린이집 보육교사들에 대한 낮은 사
회적 평가의 배경으로 보육교사 양성체계가 주요 원인으로 작 용하고 있다고 판단하고 있었다. 유치원이나 국공립 어린이집 에서 종사하고 있는 유치원교사나 보육교사들은 대학에서 전 문적인 교육을 받은 반면 대부분의 가정어린이집 보육교사들 은 보육교사교육원에서 1 년 과정을 이수했기 때문에 사회적 으로 인정받기 어렵다는 것을 직시하고 있었다. 또한, 가정어 린이집 보육교사들은 자신들이 전문지식과 능력 면에서 부족 하다는 것을 인정하고 있었다. 본 연구참여자 가정어린이집 보육교사들은 자신들이 상대적으로 자격취득이 용이한 보육 교사 양성과정 출신으로 저학력의 조건을 갖고 있기 때문에 낮은 사회적 인식을 어느 정도는 당연한 것으로 수용하고 있 었다.

그거 사실 창피해요. 그들은(유치원교사) 4 년을 공부를 했는데 당연하지. 학력이 있으니까 당연하지. (연구참여 자 \#07)

가정어린이집 교사의 권리가 잘 이루어지지 않는 게... 일단은 유치원교사라든지, 국공립이라든지 이런 기관들 은 학벌이 되고, 전문적인 교육을 받았고, 여기는 1년 과 정으로 단기간에 해서 그냥 투입되어서 하다보니까. 그 런 권리라든지... 부모님들 입장에서 보면, 요즘 세대 부 모님들은 많이 배웠잖아요. (연구참여자 \#01)

연구참여자 가정어린이집 보육교사들은 자신들이 사회적 으로 낮은 평가를 받는 데는 전문가로서 직업소명이 부족하고 교사로서 자기관리를 하지 않는 것을 지적하였다. 가정어린이 집 보육교사들은 어머니들과의 대화에 있어 전문적인 어휘사 용에 노력을 기울이지 않고, 행동에 있어서도 교사로서 자질 이 부족하기 때문에 어머니들이 전문성을 갖춘 교사로 인정하 지 않는다는 반성적인 태도를 보였다.

교사 자신에게도 문제가 있다고 생각해요. 자기계발을 안 시켜요. 예를 들면 일지를 쓰더라도 공부한 사람들은 말을 한 마디 하더라도 단어들이 달라요. 자기계발을 해 야 하는데 그냥 애 보는 사람처럼 그냥 하루 때우고 간다 는 식으로... 이런 마인드로 일하시는 분들도 있어요. 부 모님을 대할 때도 (전문)언어를 써가면서 해야 하는데 그냥 아줌마처럼 대하고. 그런 마인드 때문에 엄마들한 테 더 우리 교사들이 낮게 보여 지지 않을까. 함께 근무 하다 보면 행동도 스스로 관리를 해야 하는데 너무 관리 
가 안 되는 거 같아요. (연구참여자 \#07)

한편, 사회적 인식과 관련해 보육교사들은 언론에서 어린 이집 아동학대 사건이 이슈화될 때 마다 모든 보육교사들이 아동학대 가해자로 의심받고 있다고 토로하였다. 우리사회에 서 이슈화되고 있는 어린이집 아동학대 사건은 계속해서 언론 보도로 이어지고 있고, 보육교사들의 이미지에 부정적인 영향 을 미치고 있다. 보육교사에 대한 부정적인 사회적 인식으로 보육교사들은 직업에 대한 자긍심이 실추되어 있었고, 당당하 게 직업을 드러내는 것을 꺼리고 있었다. 직업 활동은 사회적 역할을 수행하는 것으로 외부로부터의 높은 평가와 인정이 있 을 때 직업에 대한 자긍심을 갖게 된다. 어린이집 아동학대 사 건의 언론보도는 보육교사를 아동학대의 잠재적 가해자라고 인식시키고 있었다.

전화해서 "야! 너도 애들 때리냐!" 하는 분들이 빈번하게 있으니까 기분이 안 좋은 거예요. 보육교사라고 하면 다 애 때리는 걸로 알고 있더라고요. 하도 매스컴에서 그렇 게 나오니까 “너네도 때리냐?”이런 애기하고, 비꼬듯이 자꾸 주위에서, 사회적으로 그러다 보니까. 좀 창피하고 숨기고 싶은 직업이 되는 거예요. (연구참여자 \#08)

\section{권리향상을 위한 노력}

본 연구참여자 가정어린이집 보육교사들 모두 보육교사로서 자신의 권리가 매우 취약하다라는 공통된 의견을 보였다. 취 약한 권리를 회복하기 위해 확실한 방법은 영유아보육 전공 학위를 취득하는 것이라고 믿고 있었다. 영유아보육 전공 학 위취득은 부족한 전문지식과 기술을 습득하고 내적 역량을 계 발할 수 있을 뿐만 아니라 사회적으로도 전문가로 인정을 받 을 수 있는 수단이 되기 때문이다.

지금 권리 찾으려고 공부 하는 거잖아요. 내 자신한테도 떳떳하고 싶고 부모님들한테도 조금 더 떳떳하고 싶고. 나를 조금 더 업그레이드 시키려고... (연구참여자\#06)

부모님들도 학력이 엄청 높잖아요. 어린이집에서 상담 할 때도 이게 부모님들 학력을 보게 되면 딱 깔고 가게 되더라고요. 왠지 모르게. 그래서 저도 공부를 시작하게 된 거예요. 상담할 때도 어느 정도 레벨이 좀 맞는 상태 에서 말을 할 수 있겠죠. 거기에서 저 자신이 괜히 자격
지심이 생겨서 이런 부분이 없지 않아 있었거든요. (연구 참여자 \#07)

한편, 연구참여자 가정어린이집 원장들도 가정어린이집 보 육교사들이 보육전문가로서 지식이나 역량이 부족하다고 평 가하고 있었다. 이를 극복하기 위해 보육교사들을 교육에 적 극적으로 참여시키기 위해 노력하고 있었다. 하지만 보육교 사들을 대상으로 하는 대부분의 교육이 보육시간에 이루어지 기 때문에 교육 참여에 어려움을 겪고 있었다. 보조교사 제도 가 있으나 보조교사 지원 요건이 까다롭고, 지원 신청기간 동 안 신청을 하지 않거나 지자체의 재정상황에 따라 지원을 받 을 수 없기 때문이다. 보조교사 지원을 받지 못한 가정어린이 집에서 보육교사 1 명이 낮 시간에 이루어지는 교육에 참여하 게 되면 담당 반 영유아들은 다른 반 보육교사가 맡아 주어야 하기 때문에 사실상 교육을 포기하는 경우가 빈번하게 발생하 고 있었다. 또한, 퇴근 이후에 이루어지는 교육은 보육교사들 이 참여를 꺼리고 있어 사실상 가정어린이집 보육교사들의 교 육 참여는 저조한 것으로 드러났다.

저희 시 같은 경우는 그렇게 충족이 됐어도 다 못 준대 요. 예산이 없대요. 딱 답이 예산이 없어서. 교사 교육 보 내주고 싶어요. 근데 2시 4시에 하라고 그래요. 그러면 그 허울 좋은 거잖아 교육을 어떻게 가 2시, 4 시에 못 가 요. 보조교사가 있으면 보조교사를 맡겨놓고 가잖아요. 그렇지만 원장입장에서 교육을 보내줄 수가 없어요. (원 장 \#03)

한편, 가정어린이집 원장들은 보육교사들의 언어, 태도, 복 장과 같이 전문가로서의 이미지 관리에도 신경을 쓰고 있었 다. 학부모 상담 시 전문용어를 사용하게 하고, 학부모와 접촉 할 수 있는 등.하원 시간이나 출퇴근 시 옷차림과 행동에 각별 히 주의를 기울이고 있었다. 원장들은 가정어린이집 보육교사 들에 대한 저평가의 원인으로 전문가로서의 부적절한 언어와 태도가 작용한다고 보고 있었다.

원장으로서 우리가 해야 할 의무가 교사들에게 그런 부 분들을 조금 더 알려주고 그래서 스스로가 전문가다운 모습들을 되찾을 수 있도록 수시로 알려줘야 되는 부분 들이 지금 5 년 째 하다보니까 점점 느껴지더라구요. 출 근할 때 정장차림으로 되도록 어디 현장학습을 간다거 나 그럴 때 캐쥬얼 하게 입고 가고 교사들에게도 수시로 
애기를 해줘요. (원장 \#04)

저희 같은 경우에는 계속 말씀을 하죠, 이렇게 뭐 손톱이 나 뭐 두발 이렇게 그런 복장이나 그런 거 아니면 말투 같은 거 그런 거 수시로 애기하죠. (원장 \#07)

나아가 가정어린이집 원장들은 가정어린이집이 전문적인 보육기관이라는 것을 인정받기 위해 다양한 시도를 하고 있었 다. 어린이집 행사 시 국공립 어린이집을 벤처마킹하기도 하 고, 보육교사의 1 급 자격증, 보육관련 자격증, 상장을 현관에 게시하여 보육교사들이 전문 자격을 갖추었다는 것을 적극적 으로 어필하고 있었다.

큰 어린이집처럼 이번 OT 때 대형 스크린을 해갖고 빔 을 딱 쏴가지고 했어요. 원래 저는 그렇게 안 했었거든 요. 확실히 틀려요. 선생님한테 옷이나 이런 걸 신경 쓰 라고 하고 저도 마찬가지고... 운영위원회 할 때 우리 교 사들이 영아 전담 보육 이수 같이 전문적인 걸 이수 했다 고 알리고.. (원장 \#05)

상 받은 거! 어머니들한테 그 선생님이 국회위원 상을 어 떻게 해서 받으셨다는 그거를 일일이 어머니들한테 애 기를 했어요. (원장 \#03)

\section{논의 및 결론}

본 연구에서는 영유아 보육서비스의 제공 주체인 보육교사들 이 보육과정에서 겪은 경험을 바탕으로 그들의 권리실제를 탐 색하고자 하였다. 본 연구결과 연구참여자 가정어린이집 보 육교사들 대부분은 자신들이 보육교사로서 '권리가 없다.'라 고 인식할 정도로 매우 취약하게 인식하고 있었다. 이는 B. Y. $\operatorname{Kim}$ (2011)의 연구에서 보육교사들이 보통 이상으로 권리를 침해 받고 있다고 인식한 것과 같은 결과이다. 가정어린이집 보육교사들이 교사로서 권리가 취약하다고 인식하고 있는 배 경에는 원장, 학부모, 보육관련 제도 및 법, 사회적 인식 등 여 러 요인들이 영향을 미치고 있었다. 중요한 점은 가정어린이 집 보육교사들의 취약한 권리는 어린이집을 이용하고 있는 영 유아에게 직 - 간접적으로 영향을 미친다는 것이다. 본 연구결 과 실제로 가정어린이집의 원장겸직 제도는 보육교사들의 업 무를 가중시킬 뿐만 아니라 보육의 질을 저하시키고 있었다.
이는 원장겸직 제도로 인해 원장의 업무공백을 다른 교사들이 나누어 담임역할을 지원하게 되어 초과보육이 발생하게 된다 고 지적한 J. Y. Lee와 Kim (2016)의 연구결과와 일치한다. 즉, 가정어린이집 보육교사들은 '근무여건 개선 및 생활보장 요구 권'을 보장받지 못하고 있다. G. Kim (2016)은 이는 보육활동 에 전념할 수 있도록 보장받아야 하는 권리로 보육의 효과와 능률을 높이기 위해 적정량의 업무부담과 적합한 근무여건을 개선할 권리라고 주장하였다. 원장겸직 제도로 인해 가정어린 이집의 영아반에서 초과보육이 발생하게 되고 이는 결과적으 로 영아 돌봄에 필요한 적정한 물리적 시간이나 보육의 질을 담보할 수 없게 된다. 연구참여자 가정어린이집 보육교사들은 시급하게 개선되어야 할 제도로 원장겸직제도를 지적하였으 며, 초과보육으로 제대로 영유아를 돌보지 못하게 되는 상황 이 발생되는 것을 우려하였다. 가정어린이집을 이용하는 영아 의 수는 340,443명으로 민간어린이집 379,913명 다음으로 높 은 비율을 차지하고 있다(KICCE, 2016). 영아기는 발달단계 상 양육자의 세심한 돌봄이 특별히 더 요구되는 시기로 원장 겸직제도로 인해 발생되는 가정어린이집의 초과보육에 대한 심도 깊은 논의가 필요하다.

한편, 가정어린이집 보육교사들은 원장과의 상호관계에서 권리를 보장받지 못하는 것으로 나타났다. 가정어린이집 원장 의 보육활동에 대한 잦은 통제로 전문가로서의 자율권을 보장 받지 못하고 있었다. B. Y. Kim (2011)이 수행한 보육교사의 권 리와 의무에 관한 인식조사에서 어린이집 형태에 따라 차이를 보였는데 가정어린이집은 학부모와 원장, 행정기관 순으로 침 해주체를 인식하고 있었으며, 민간보육시설은 학부모와 행정 기관, 직장보육시설은 학부모, 국공립보육시설은 행정기관, 학 부모 순으로 나타났다. 이는 가정어린이집 보육교사들이 원장 과의 상호관계에서 권리를 침해받고 있다는 본 연구결과와 같 다. 가정어린이집은 소규모의 조직으로 원장의 영향력이 클 수 밖에 없는데(J. H. Kang \& Kim, 2013) 가정어린이집은 보육교 사가 수행하는 보육업무의 상당 부분에 원장의 직·간접적인 통 제가 이루어지고 있었다. 소규모 조직 내에서 원장의 재량이 많을 수밖에 없고 원장의 리더십이 보육교사의 이직에 크게 영 향을 미치게 된다(Yun \& Jeon, 2015). E. J. Lee와 Yang (2012)은 보육교사의 잦은 이직 요인으로 원장과의 부정적인 경험을 지 적하였는데, 위의 두 선행연구는 본 연구결과와 같은 맥락이 다. 보육교사의 잦은 이직은 보육교사의 전문성 저하와 영유아 와의 안정적인 애착형성에도 부정적인 영향을 미치게 된다. G. $\operatorname{Kim}$ (2016)은 전문직으로서의 자율권에서 보육교사들은 관련 법제도가 갖추어져 있지 않다고 밝혔다. 보육교사들이 전문가 
로서의 자율권을 보장받기 위해서 법제도 마련과 함께 어린이 집에서는 보육교사의 전문성을 인정하고 보육활동에 관한 자 율성을 지지해주는 원장의 리더십이 요구된다.

한편, 정부의 보육교사 근로환경 개선책은 사실상 가정어 린이집에서는 적용되지 못하고 있었다. 보조교사와 대체교사 제도를 도입하였으나 도움이 필요할 때 지원을 받을 수 없어 보육교사들은 교육 참여에 제한을 받고 있었다. 가정어린이집 보육교사들은 사회적으로 전문성을 인정받지 못하고 있다고 인식하고 있어 교육의 필요성이 강조된다. 하지만 전문성 함 양을 위해 지속적으로 교육을 받을 수 있는 교육권은 현실적 으로 실현되지 못하고 있는 실정이다. 교육 참여 시 발생하는 업무공백을 다른 보육교사가 지원해야 하나 보육의 주요 업무 는 영유아를 돌보는 일로 다른 반을 담당하고 있는 보육교사 의 지원이 사실상 이루어지기 어렵다. 보조교사와 대체교사 제도가 유연성을 갖고 어린이집의 상황에 맞게 탄력적으로 대 처하여 보육교사들의 교육 참여에 어려움이 발생되지 않아야 한다. 또한, 가정어린이집 보육교사들의 복지후생과 관련한 권리부분에서 취약성이 여실히 드러났다. Koo와 Jung (2016) 이 실시한 교사 권리에 대한 개념도 분석연구에서 보육교사 들은 '생활보장'과 ‘근무환경'을 중요하게 인식하고 있는 것으 로 밝혀졌다. 실제로 가정어린이집 보육교사들은 정신적, 신 체적으로 강도 높은 업무를 수행하고 있지만 제대로 휴식시간 이 주어지지 않으며, 월차나 병가 같은 휴가를 사용하는데도 제한이 있었다. 보육교사의 휴가는 보육 공백을 최소화할 수 있도록 대체교사나 그 밖의 인력을 배치해야 하지만 NHRC (2012)의 조사에서도 대체교사의 부족으로 자율적으로 휴가 를 신청하기 어려울 뿐만 아니라 자신의 업무를 봐야하는 동 료교사들의 고충이 부담스러워 연월차 사용을 잘 하지 않는 것으로 나타났다. 가정어린이집 보육교사들의 휴가사용 제한 에 있어 Jeon과 Lee (2014)는 소수의 교직원이 근무하기 때문 에 휴가 사용 시 대체할 만한 교사가 없는 것을 원인으로 지적 한 바 있다. 이에 대해 보육교사 자격과 경력이 있는 보육교사 인력 풀을 다양하게 마련하는 것을 대안으로 고려해 볼 수 있 다. 보육현장에서 일어날 수 있는 다양한 상황을 고려하여 교 사 지원이 즉시 이루어질 수 있도록 시스템 마련이 필요하다. 보육교사가 교육에 참여하거나 휴가 시 영유아에게는 보육공 백을 예방하고 교사에게는 교육권과 휴가사용을 보장할 수 있 는 효과를 나타낼 수 있다.

가정어린이집 보육교사들의 고용보장은 매우 취약한 것으 로 드러났는데, 현재 보육원아에 따라 보육료 지원이 이루어 지고 있어 정원이 충족되지 못할 때 교사의 인건비 확보가 어
려울 수밖에 없다. 따라서 현장에서는 원아 충족이 안 될 경우 보육교사의 급여 삭감이나 해고로 이어지고 있는 실정이다. 교사의 신분 불안정으로 야기되는 문제는 사회적 손실을 가져 오게 된다(Wi, 2005). 영유아보육법 제2조에 의하면 보육이란 영유아를 건강하고 안전하게 보호.양육하고 영유아의 발달 특 성에 맞는 교육을 제공하는 사회복지서비스를 말한다(Infant Care Act, Act No. 14001, 2016). 따라서 사회복지서비스를 제 공하고 있는 보육교사의 신분 불안정은 사회적 손실을 가져오 게 되는데, 보육서비스의 제공 주체인 보육교사와 이용자인 영유아가 직접적인 피해 당사자가 된다. 보육교사들의 고용안 정을 위해 보육원아 수에 따른 보육료 지원을 면밀하게 검토 해볼 필요가 있다.

가정어린이집 보육교사를 전문가로 인정하지 않는 사회적 인식도 그들의 권리실현에 장애가 되고 있었다. 보육교사의 전문성은 보육교사의 자질, 외적 조건 그리고 사회적 인정이 조화롭게 형성되었을 때 발휘된다. 하지만 가정어린이집 보육 교사들이 보육활동 과정에서 전문성을 발휘할 정도로 충분한 사회적 인정은 못 받고 있다. 특히 보육서비스를 이용자인 학 부모들로부터 전문교사로 인정받기보다 보호모와 같은 역할 수행자로 낮게 평가받는다고 인식하고 있었다. Ko (2012)의 연구에서도 주변인이 갖는 보육교사에 대한 인식은 '전문성이 낮은 직업'으로 나타났다. 가정어린이집 보육교사를 전문교사 로 인정하지 않는 데는 낮은 학력, 저임금, 용이한 자격취득 등 여러 요인이 작용하고 있다. 외부로부터의 낮은 평가는 스스 로 전문가라고 느끼는 자부심을 저하시킬 뿐만 아니라 보육업 무를 효율적으로 수행하는데도 영향을 미치게 된다(Park, Wee, \& Yang, 2014). 특히, 아동학대 사건의 언론보도는 전문교사로 서의 긍정적인 이미지를 실추시키고 있었다. 언론매체의 어린 이집 부정행위 보도는 보육교사를 교육에 종사하는 전문가라 기보다 불법을 행하는 죄인으로 보는 시각이 커지는 데에 기 인한 것으로 보고 있다(Jeon \& Lee, 2014). 어린이집은 지역사 회와 적극적인 상호작용으로 주민들과는 우호적인 관계형성 을 위한 노력을 이루어야하며, 한편으로는 아이를 믿고 맡길 수 있는 보육 전문기관으로서 신뢰를 형성해야 한다. 또한, 보 육교사들의 사기 진작을 위해 역량 있는 보육교사들을 발굴하 여 인센티브를 주는 것도 방법이 될 수 있다.

아동학대 예방차원에서 마련된 CCTV 설치는 학부모의 권 리측면에서는 어느 정도 보장이 이루어지고 있었으나 보육교 사의 권리보호는 고려되지 않고 있었다. 영유아보호법 제 15 조(영상정보의 열람금지 등)에 의하면 보호자가 자녀 또는 보 호아동의 안전을 확인할 목적으로 열람시기.절차 및 방법 등 
보건복지부령으로 정하는 바에 따라 요청하는 경우(CWA, Act No. 14086,2016 ) 어린이집에 열람요청서나 의사 소견서를 제 출하여 영상정보의 열람을 요청할 수 있으며, 어린이집에서는 요청을 받은 날로부터 10 일 이내에 열람 장소 등을 정하여 보 호자에게 통지하도록 하였다. CCTV 열람과 관련한 법 조항 에서 보육교사의 권리는 언급되지 않고 있다. 본 연구결과 가 정어린이집에서 학부모가 아동학대 의심으로 CCTV 열람을 요청할 경우 보육교사의 의견수렴 절차나 열람 시 해당 보육 교사 동반과 같은 선행과정은 고려되지 않고 있었다. CCTV 열람은 무엇보다 자신의 업무수행 과정에서 발생한 일을 확인 하는 것이므로 당사자인 보육교사의 의견수렴이나 참여가 전 제되어야 한다. 이를 뒷받침하기 위해 CCTV 관련 규정에서 보육교사의 권리부분을 구체적으로 명시할 필요가 있다.

본 연구는 가정어린이집 보육교사들의 권리실제와 관련된 경험을 통해 향후 보육교사의 권리향상에 필요한 실질적인 내 용을 제공하였다는데 의의가 있다. 나아가 보육교사들의 권 리확보는 어린이집을 이용하는 영유아의 권리실현에 있어 수 반되어야 하는 필수요인임을 확인하였다. 따라서 보육서비스 의 질 관리를 위해 보육교사들이 전문가로서 권리실현을 할 수 있도록 체계적인 지원이 이루어져야 할 것이다. 이에 권리 실현을 위한 지원방안이 어떻게 효과를 이루고 있는지에 대한 후속 연구가 필요할 것이다. 본 연구의 제한점으로는 현장관 찰을 통해 연구참여자인 내부자의 관점과 연구자인 외부자적 관점의 통합 접근을 이루지 못한 것이다.

\section{Notes}

This study was presented as a poster at the 2016 Annual Fall Conference of the Korean Association of Child Studies.

\section{Conflict of Interest}

No potential conflict of interest relevant to this article was reported.

\section{References}

\section{In English}

David, L. M. (1997). Focus groups as qualitative research. Thousand Oaks, CA: Sage.

Park, S., Wee, S.-J., \& Yang, S. (2014). Are we experts? Perspectives of Korean teachers on their careers in infant and toddler care. Australasian Journal of Early Childhood, 39(1), 56-64. Retrieved from http://www.riss.kr/link?id=O64867484

Schwandt, T. A. (2007). The sage dictionary of qualitative inquiry. Thousand Oaks, CA: Sage.

\section{In Korean}

Child Welfare Act, Act No. 14058, 2016. Retrieved from http:// www.law.go.kr

Han, M. R. (1993). A theoretical study on the improvement of the qualitative level of child care facilities. Journal of Education \& Culture, 3, 149-165. Retrieved from http://www.riss.kr/ link?id=A3026664

Infant Care Act, Act No. 14001, 2016. Retrieved from http://www. law.go.kr

Child Welfare Act, Act No. 14058, 2016. Retrieved from http:// www.law.go.kr

Jeon, S. G., \& Lee, D. K. (2014). A study on difficulties and joys of teachers in home daycare center. Korean Society Children's Literature \& Education, 15(1), 253-282. Retrieved from http://www.riss.kr/link?id=A99963596

Kang, B. J., \& Kim, J. S. (2014). Care-giving teaches' personalities/ emotional labors and their organization culture and its impact on their respect of infants and children's rights. Korean Journal of After-School Child Education, 11(2), 7796. Retrieved from http://www.riss.kr/link?id=A100532418

Kang, J. H., \& Kim, J. Y. (2013). Relationships between family child care teacher's job satisfaction and turnover intention. Korea Journal of Child Care and Education, 76, 121-138. Retrieved from http://www.riss.kr/link?id=A99593176

Kim, B. Y. (2011). Recognition on the rights and duties of childcare teachers. Journal of Early Childhood Education \& Educare Welfare, 15(2), 7-24. Retrieved from http://www. riss.kr/link?id=A82623009

Kim, G. (2016). A study on the legal analysis related to the rights of kindergarten-daycare teacher. Korean Journal of Child Care and Education Policy, 10(1), 31-47. Retrieved from http://www.riss.kr/link?id=A101896538

Kim, G, S., Moon, M, G., \& Lee, M. K. (2015). Plan for Strengthening and protection the right of kindergarten daycare teachers (Report No. 2015-06). Seoul: Korea Institution 
Child Care and Education.

Koo, E. M., \& Jung, H. Y. (2016). An analysis of the concept map of childcare center teachers and kindergarten teachers about their rights. Korean Journal of Child Care and Education, 96, 1-27. Retrieved from http://www.riss.kr/ link?id=A101734381

Ko, J. U. (2012). A study of solution on child care teachers emotional labor. Journal of Early Childhood Education \& Educare Welfare, 16(2), 271-294. Retrieved from http:// www.riss.kr/link?id=A60126587

Korea Institution Child Care and Education. (2016). 2015 childcare statistics. Retrieved from http://www.kicce.re.kr

Lee, D. R. (2016). Analysis on perception gap between teacher and parents regarding respect for young children' right during child care center's and on teachers' conflict (Master's thesis). Retrieved from http://www.riss.kr/link?id=T14021817

Lee, E. J., \& Yang, S. E. (2012). A qualitative study on the turnover experiences of teachers and directors of child care centers. Journal of the Korean Home Management Association, 30(2), 121-136. Retrieved from http://www. riss.kr/link?id=A60153510

Lee, J. Y., \& Kim, H. J. (2016). The significance of home daycare directors' experiences executing multiple duties. Korean Education Inquiry, 34(1), 45-67. Retrieved from http:// www.earticle.net/Article.aspx?sn=270464

National Human Rights Commission. (2012). Survey on human rights of child care teachers. Retrieved from http://library. humanrights.go.kr/hermes/imgview/12-90.pdf

Seo, Y. S. (2010, October). Child rights and childcare teacher expertise. Paper presented at the 2010 Fall Conference of the Korea Association of Child Education and Care, Seoul, Korea.

Wi, M. S. (2005). A analysis study on the duty and right of teacher. The Journal of Education Administration, 23(1), 209-237. Retrieved from http://www.riss.kr/link?id=A76483207

Yun, K. M., \& Jeon, B. J. (2015). A comparative study on the turnover intention of teacher by child care center's types. Journal of Digital Convergency, 13(1), 25-35. Retrieved from http://www.riss.kr/link?id=A100297860

\section{ORCID}

Gihwa Kim

Sungeun Yang http://orcid.org/0000-0001-9691-4859

http://orcid.org/0000-0002-8666-3694
Received December 31, 2016 Revision received February 10, 2017 Accepted February 19, 2017 